This item was submitted to Loughborough's Research Repository by the author.

Items in Figshare are protected by copyright, with all rights reserved, unless otherwise indicated.

\title{
Body mapping of thermal sensitivity to skin wetness across the torso
}

\section{PLEASE CITE THE PUBLISHED VERSION}

http://www.acsm.org/access-public-information/acsm-journals/medicine-science-in-sports-exercise

\section{PUBLISHER}

American College of Sports Medicine

\section{VERSION}

AM (Accepted Manuscript)

\section{PUBLISHER STATEMENT}

This work is made available according to the conditions of the Creative Commons Attribution-NonCommercialNoDerivatives 4.0 International (CC BY-NC-ND 4.0) licence. Full details of this licence are available at: https://creativecommons.org/licenses/by-nc-nd/4.0/

\section{LICENCE}

CC BY-NC-ND 4.0

\section{REPOSITORY RECORD}

Filingeri, Davide, Bernard Redortier, S.G. Hodder, and George Havenith. 2019. "Body Mapping of Thermal Sensitivity to Skin Wetness Across the Torso". figshare. https://hdl.handle.net/2134/15648. 


\section{Body mapping of thermal sensitivity to skin wetness across the torso}

Davide Filingeri ${ }^{1}$, Bernard Redortier ${ }^{2}$, Simon Hodder ${ }^{1}$, George Havenith ${ }^{1}:{ }^{1}$ Environmental Ergonomics Research Centre, Loughborough University, Loughborough, UK, ${ }^{2}$ Thermal Sciences Laboratory, Oxylane Research, Villeneuve d’Ascq, France

Humidity receptors have never been identified on human skin and the ability to perceive skin wetness has been suggested to rely on the sensory inputs arising from thermal cold afferents. However, limited data are available on how thermal afferents and their regional distribution influence the perception of wetness. PURPOSE: Given the regional variability in thermal sensitivity across the torso, here we examined whether regional differences in the sensitivity to wetness exist. METHODS: Sixteen male participants (20 $\pm 2 \mathrm{yrs}$ ) were tested at rest. Twelve regions of the torso (6 front - 6 back) were stimulated (duration: 10s) with a dry or wet thermal probe $\left(25 \mathrm{~cm}^{2}\right)$ set at a temperature of $15^{\circ} \mathrm{C}$ below the local skin temperature $\left(\mathrm{T}_{\mathrm{sk}}\right)$, which was measured pre and post stimulation with an infrared thermometer. Thermal and wetness sensations were recorded using likert scales (going from warm to very cold and from dry to dripping wet). RESULTS: In response to the same relative cold stimuli, the skin cooling response varied by location and regional differences were found both in thermal and wetness sensations. Changes in local $\mathrm{T}_{\text {sk }}$ from baseline varied in a range of $-1.9 \pm 1.5^{\circ} \mathrm{C}$ (i.e. medial lower back) to $-4.3 \pm 1.5^{\circ} \mathrm{C}$ (i.e. lateral chest). Thermal sensation scores varied in a range of $-2.1 \pm 1$ "slightly cool” (i.e. medial chest) to $-4.1 \pm 0.9$ “cold” (lateral lower back). Overall, colder sensations were reported on the lateral abdomen and lower back. Wetness perception scores varied in a range of $-1 \pm 0.8$ "neutral to slightly wet" (i.e. medial upper abdomen) to $-2 \pm 1.3$ "slightly wet” (i.e. medial lower back). Overall, greater wetness was reported on the lower back. No differences were perceived between wet and dry stimuli, the dry ones perceived as wet as the wet ones. For a better visual comparison, body maps of thermal and wetness sensitivity were developed. The regional variability in wetness sensitivity showed a pattern similar to the thermal sensitivity to cold. CONCLUSION: We conclude that, as thermal cold afferents seem to have a critical role in driving the perception of wetness, based on the regional variability in thermal sensitivity humans present regional differences in the cutaneous sensitivity to wetness across the torso. 